Supporting Information

\title{
The Release of NO from Reduced Nitroprusside Ion. Metal-Dinitrosyl Formation and NO-Disproportionation Reactions
}

Federico Roncaroli, Rudi van Eldik, and José A. Olabe 


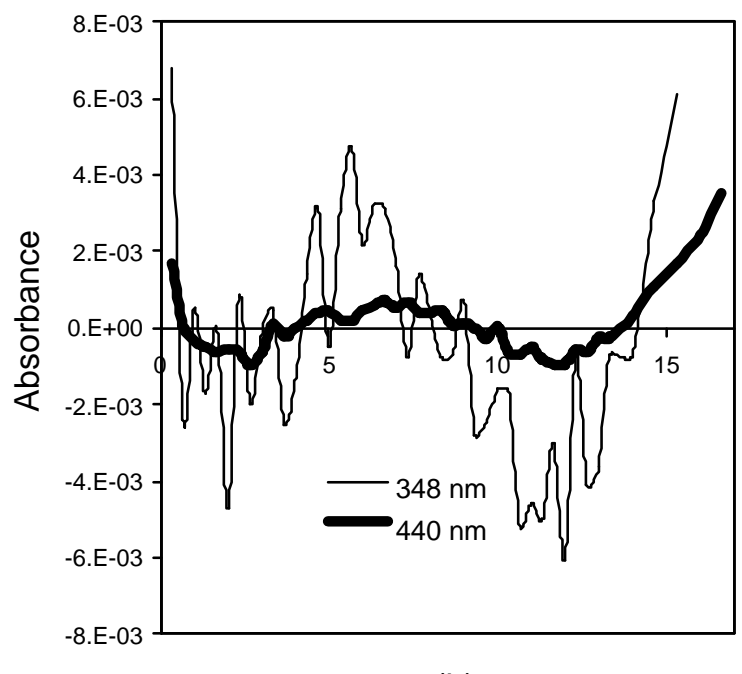

$\mathrm{t}(\mathrm{h})$

Figure SI 1a): Residues of the SPECFIT analysis from the experiment at pH 9.0 (see Figure 1).

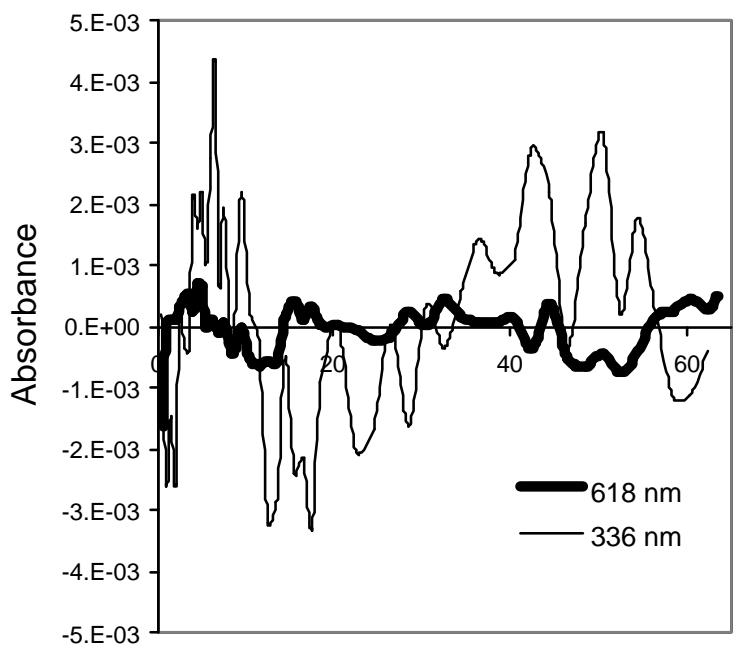

$\mathrm{t}(\mathrm{h})$

Figure SI 1b): Residues of the SPECFIT analysis from the experiment at pH 6.0 (see Figure 3) 


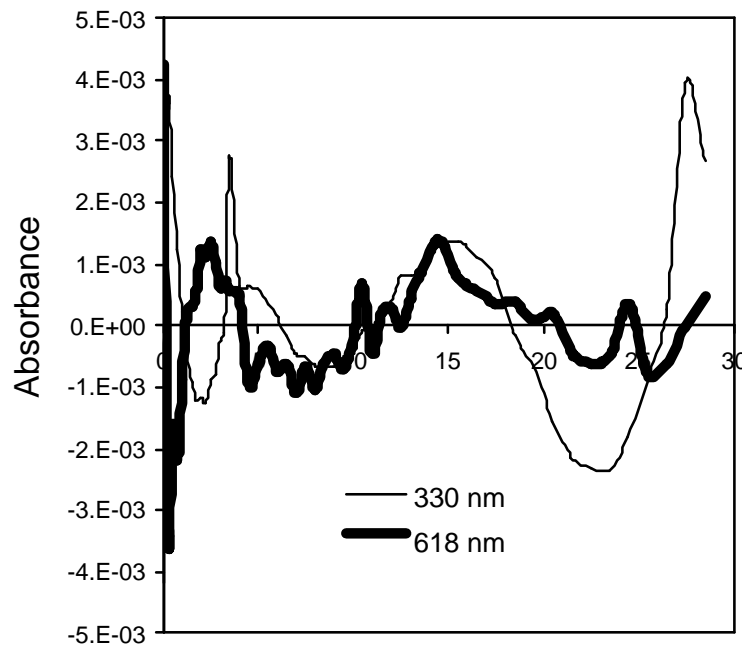

$\mathrm{t}(\mathrm{h})$

Figure SI 1c): Residues of the SPECFIT analysis from the experiment at $\mathrm{pH} 5.0$ (reductant: $\left.\mathrm{NaBH}_{4}\right)($ see Figure 7).

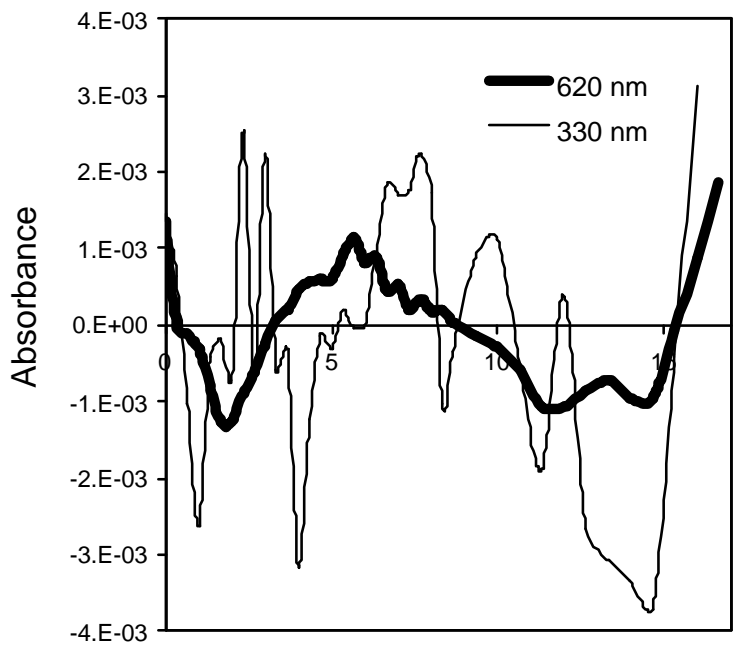

$\mathrm{t}(\mathrm{h})$

Figure SI 1d): Residues of the SPECFIT analysis from the experiment at pH 5.0 (reductant: $\mathrm{Na}_{2} \mathrm{~S}_{2} \mathrm{O}_{4}$ ). (see Figure SI 6). 


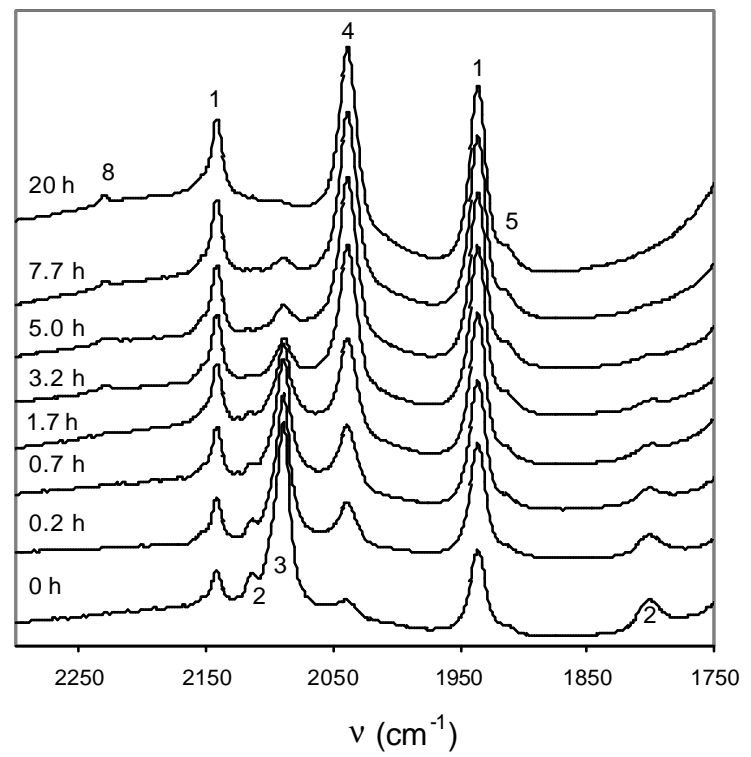

Figure SI 2: IR spectral changes observed during the decomposition of a solution $c a .17 \mathrm{mM}$ in reduced NP, (reductant: $\left.\mathrm{Na}_{2} \mathrm{~S}_{2} \mathrm{O}_{4}\right)$, at pH $7\left(T=25{ }^{\circ} \mathrm{C}, 0.5 \mathrm{M}\right.$ phosphate buffer).in $\mathrm{H} \underline{2}, k_{o b s} c a .8 \times 10^{-5} \mathrm{~s}^{-1}$. Peak numbers correspond to: $1,\left[\mathrm{Fe}(\mathrm{CN})_{5} \mathrm{NO}\right]^{2-} ; 2,\left[\mathrm{Fe}(\mathrm{CN})_{4} \mathrm{NO}\right]^{2-} ; 3,\left[\mathrm{Fe}(\mathrm{CN})_{5} \mathrm{NO}\right]^{3-} ; 4,\left[\mathrm{Fe}(\mathrm{CN})_{6}\right]^{4} ; 5$, $\left[\mathrm{Fe}(\mathrm{CN})_{4}(\mathrm{OH}) \mathrm{NO}^{2-} ; 8, \mathrm{~N}_{2} \mathrm{O}\right.$; as detailed in Table 1. 


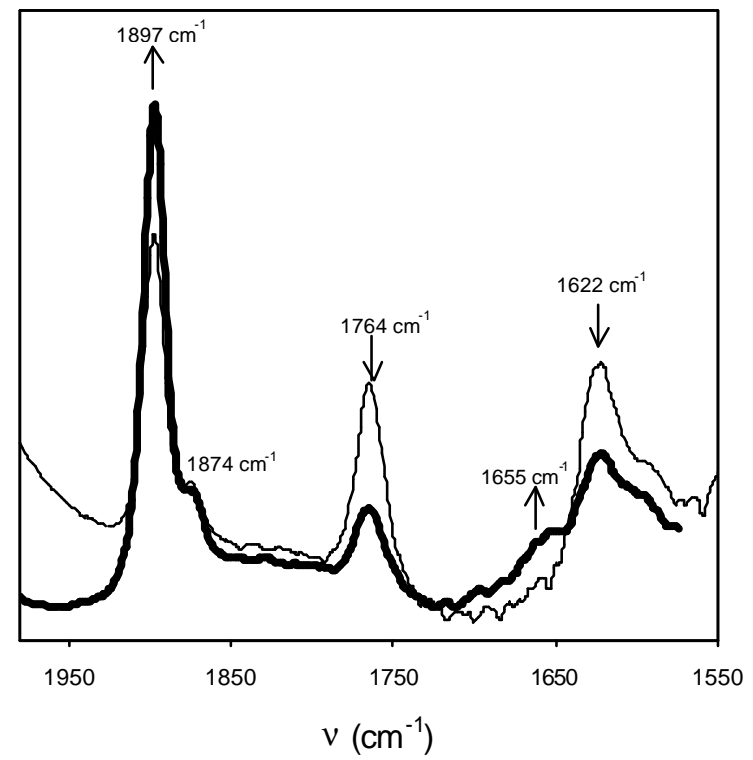

Figure SI 3: IR spectral changes observed during the decomposition of a solution $c a 15 \mathrm{mM}$ in $\left[\mathrm{Fe}(\mathrm{CN})_{5}\left({ }^{15} \mathrm{NO}\right)\right]^{3-}$ (reductant: $\left.\mathrm{Na}_{2} \mathrm{~S}_{2} \mathrm{O}_{4}\right)$ in $\mathrm{D}_{2} \mathrm{O}$ at $\mathrm{pH} 7\left(T=25{ }^{\circ} \mathrm{C}, 0.5 \mathrm{M}\right.$ phosphate buffer). The second spectrum was recorded after 2 hours. Arrows indicate the evolution of the spectra. The peaks at 1897, 1874, 1764, 1655 and $1622 \mathrm{~cm}^{-1}$ correspond to the complexes $\left[\mathrm{Fe}(\mathrm{CN})_{5}{ }^{15} \mathrm{NO}\right]^{2-},\left[\mathrm{Fe}(\mathrm{CN})_{4}(\mathrm{OH})^{15} \mathrm{NO}\right]^{2-}$, $\left[\mathrm{Fe}(\mathrm{CN})_{4}{ }^{15} \mathrm{NO}\right]^{2-}$, doubly labeled $I_{1}$ and $\left[\mathrm{Fe}(\mathrm{CN})_{5}{ }^{15} \mathrm{NO}\right]^{3-}$, respectively. 


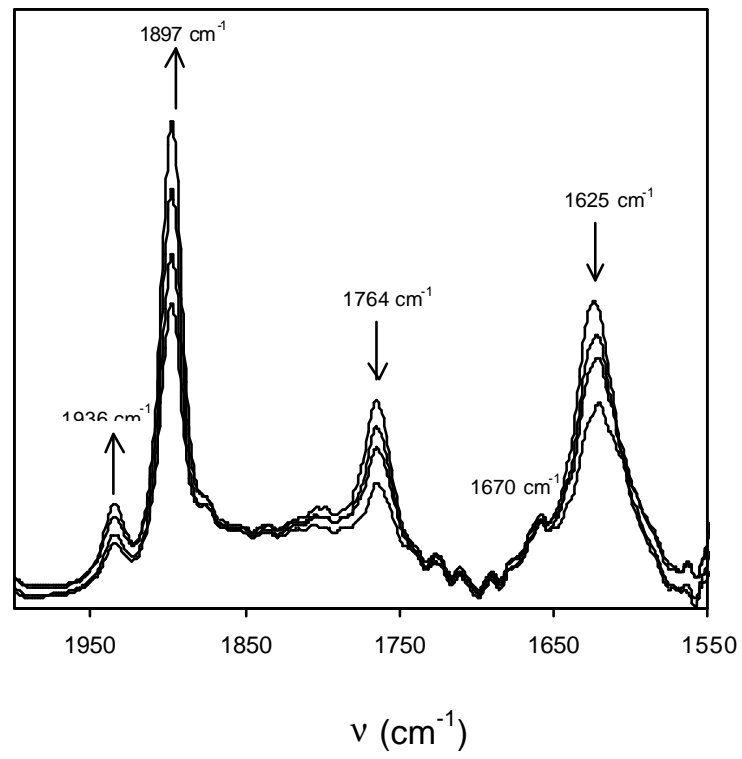

Figure SI 4: IR spectral changes recorded during the decomposition of a solution ca $15 \mathrm{mM}$ in reduced $\left[\mathrm{Fe}(\mathrm{CN})_{5}\left({ }^{15} \mathrm{NO}\right)\right]^{3-}$ (reductant: $\left.\mathrm{Na}_{2} \mathrm{~S}_{2} \mathrm{O}_{4}\right)$ in $\mathrm{D}_{2} \mathrm{O}$ in the presence of small amounts of ${ }^{14} \mathrm{NO} \mathrm{pH} 7\left(\mathrm{~T}=25{ }^{\circ} \mathrm{C}\right.$, $0.5 \mathrm{M}$ phosphate buffer). Spectra recorded at 0, 6, 14 and 27 minutes. The peaks at 1936; 1897, 1764, 1670 and $1625 \mathrm{~cm}^{-1}$ correspond to the complexes $\left[\mathrm{Fe}(\mathrm{CN})_{5}{ }^{14} \mathrm{NO}\right]^{2-},\left[\mathrm{Fe}(\mathrm{CN})_{5}{ }^{15} \mathrm{NO}\right]^{2-},\left[\mathrm{Fe}(\mathrm{CN})_{4}{ }^{15} \mathrm{NO}\right]^{2-}$, singly labeled $I_{1}$ and $\left[\mathrm{Fe}(\mathrm{CN})_{5}{ }^{15} \mathrm{NO}\right]^{3-}$, respectively. Arrows indicate the time evolution of the spectra. 


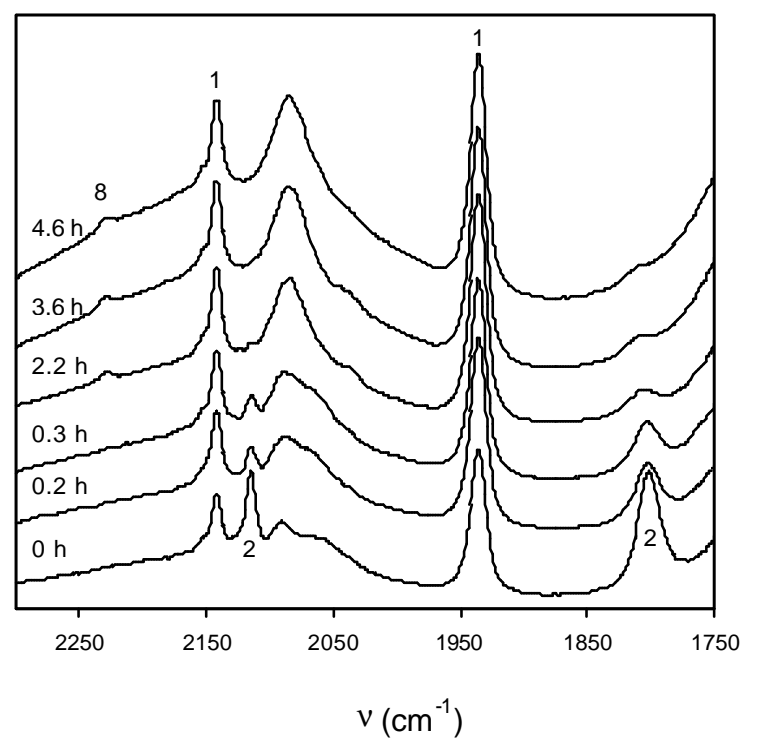

Figure SI 5: IR spectral changes observed during the decomposition of a solution ca. $17 \mathrm{mM}$ in reduced nitroprusside (reductant: $\left.\mathrm{Na}_{2} \mathrm{~S}_{2} \mathrm{O}_{4}\right)$ at $\mathrm{pH} 4\left(T=25{ }^{\circ} \mathrm{C}, 0.5 \mathrm{M}\right.$ acetate buffer), in $\mathrm{H}_{2} \mathrm{O}, k_{\text {obs }} c a .1 \times 10^{-3} \mathrm{~s}^{-1}$. Peak numbers correspond to: $1,\left[\mathrm{Fe}(\mathrm{CN})_{5} \mathrm{NO}\right]^{2-} ; 2,\left[\mathrm{Fe}(\mathrm{CN})_{4} \mathrm{NO}\right]^{2-} ; 8, \mathrm{~N}_{2} \mathrm{O}$; as detailed in Table 1 


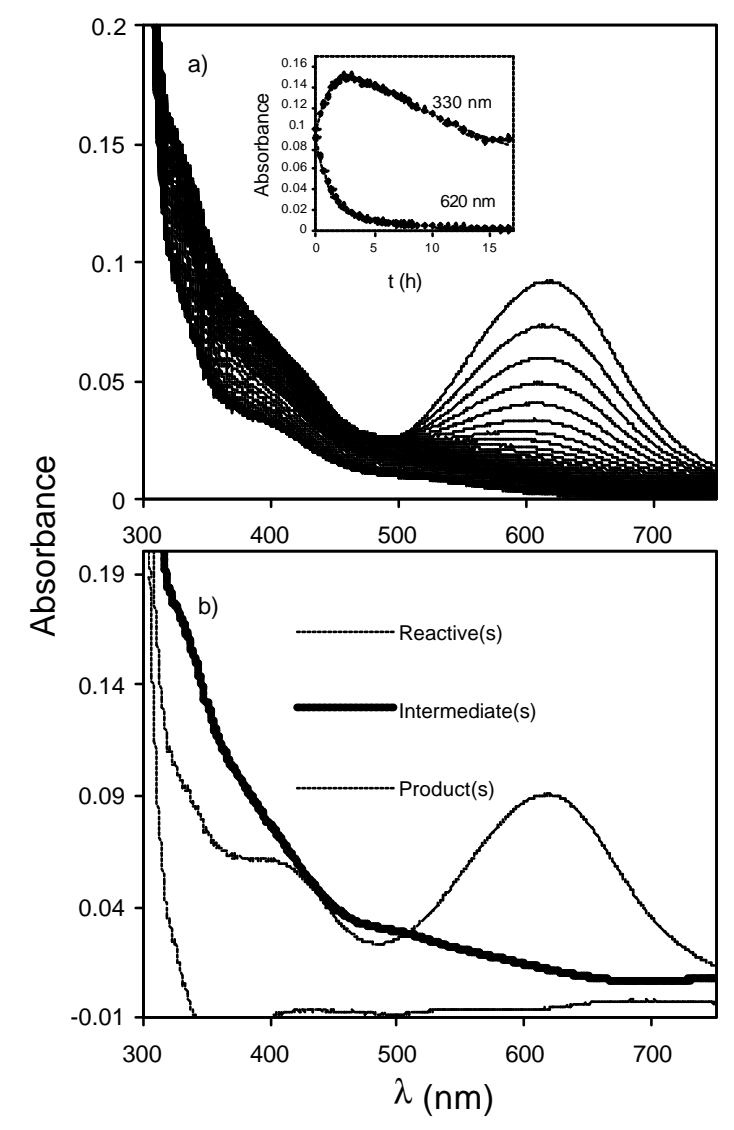

Figure SI 6. a) UV-vis spectral changes observed during the decomposition of a solution ca. $0.26 \mathrm{mM}$ in reduced nitroprusside (reductant: $\left.\mathrm{Na}_{2} \mathrm{~S}_{2} \mathrm{O}_{4}\right)$ at pH $5.2\left(I=0.1 \mathrm{M}, T=25.5{ }^{\circ} \mathrm{C}, 0.01 \mathrm{M}\right.$ Acetate buffer), cycle time $1200 \mathrm{~s}$ and $2400 \mathrm{~s}$ after $36000 \mathrm{~s}$. Inset: kinetic traces at $330 \mathrm{~nm}$ and $618 \mathrm{~nm}$ fitted to a double exponential

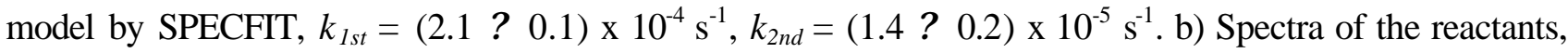
intermediates and products obtained from the SPECFIT analysis 


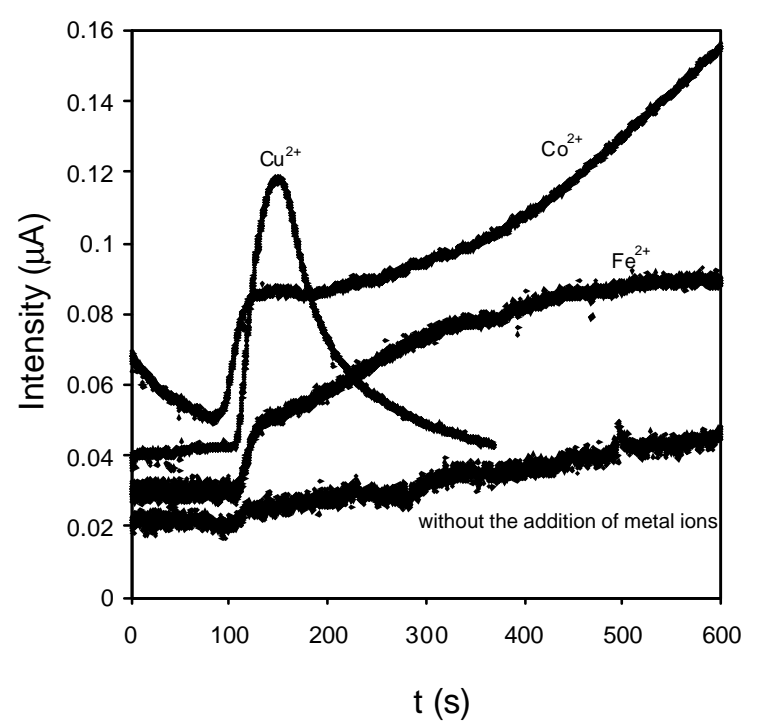

Figure SI 7: Chronoamperograms for the release of $\mathrm{NO}$ after addition of $3 \mathrm{mg}$ of $\mathrm{Na}_{2} \mathrm{~S}_{2} \mathrm{O}_{4}$ to $10 \mathrm{~mL}$ of 3.3 $\mathrm{mM}$ nitroprusside solution at $\mathrm{pH} 7$, in the presence of $9-10 \mathrm{mM}$ of different metal ions. 